\title{
RS1 Gene
}

National Cancer Institute

\section{Source}

National Cancer Institute. RS1 Gene. NCI Thesaurus. Code C75571.

This gene is involved in development, aging, and cell-cell adhesion in the retina. 